\title{
Development of Physical Practicum Guidelines with Mentorship Approach Using Problem Based Learning Model
}

\author{
Djeli Tulandi* Tineke Rondonuwu \\ Pendidikan Fisika FMIPA Universitas Negeri Manado, Sulawesi Utara, Indonesia
}

\begin{abstract}
The purpose of this study was to produce a basic physics practicum product for microscope tools using a problembased learning model. This research is a development research adapted from the Thiagarajan model. The samples taken consisted of 3 student groups each group of 5 people and 1 large class group of 20 people. In the pilot trials in small groups using a mentoring approach. Data analysis techniques were carried out descriptively which departed from observations of the completeness of guidelines and implementation of guidelines through the stages of the problem-based learning model. The results of the study related to the guideline design based on the completeness of the elements in the practicum guide showed that the percentage of completeness of the guidelines after revision 1 was $37.5 \%$, after review 2 it was $70.83 \%$ and in review 3 it was $95.83 \%$. . The results of field tests for students taking basic physics 2 as many as 20 people who were asked for opinions on the use of guidelines and practicum implementation showed that $62.5 \%$ of students gave a choice of Strongly Agree category, $36.25 \%$ of students gave the option of Agree and there were $1.25 \%$ for the option of Disagreeable category and no student gives a choice of the category "Disagree". Based on this data shows that there are $98.75 \%$ of the number of students who respond positively to the use of practicum guides.Based on the results of the study it can be concluded that a basic physics practicum guide product has been produced for the microscope tool using a problem-based learning model with a mentoring approach with excellent and decent qualifications. Through this research, students as prospective teachers have experience developing guidelines to carry out science processes to build interaction and communication and class management.
\end{abstract}

Keywords: Practical Guide, Research and Development, Microscope, Problem Based Learning.

DOI: $10.7176 / \mathrm{JEP} / 10-22-07$

Publication date: August $31^{\text {st }} 2019$

\section{Introduction}

Quality education will produce quality human resources. Building quality human resources certainly requires a quality learning process. The learning process in higher education, especially in the physics education study program, is very close to practicum activities, because there are several subjects that are integrated with practicum. One of the practicum courses is Basic Physics II with the weight of SKS 4. Topic topics in basic physics courses including optical instruments are important for students to understand because they will provide basic knowledge of physics and expedite lectures in the next semester and have the potential to shape generation knowledge and skills the future, and can play an important role in preparing quality teachers for the 21 st century.[1]

Practical activities are a teaching tool that helps students understand the science process. Practicum implementation is very important and no doubt in science learning [2,3]9,5. Based on the results of the question and answer session with students who took the Basic Physics II course, it was revealed that the Basic Physics II course was one of the difficult subjects. The results of the semester exam results in the study program show that generally the results of student examinations for basic physics and other subjects with basic physics requirements have not been satisfactory. Constraints in the implementation of basic physics practicum II besides the lack of tools also the availability of standard guidelines is still limited, including guidelines for the use of microscopes. A good practicum guide will make it easier for students to carry out practicum correctly and guide students to follow the chosen learning model. Scientific inquiry refers to the various ways in which scientists study the natural world and propose explanations based on the evidence gathered. This also refers to student activities where they develop knowledge and understanding of scientific ideas, among others, through laboratory activities [4].

The development of a practicum guide is integrated with the problem-based learning model. Problem based learning model (Problem based Learning), is a learning model that makes the problem as the basis or basis for students to learn. Problem-based learning is part of intellectual skills, not just memorizing facts, information, principles, formulas, and so on. Problem solving aims to enable students to solve problems and be able to understand the content behind the problem. Also so students understand the problem solving process and develop it as learning to organize and control student learning on their own [5]. Problem solving also aims so that students can learn to collect and process information independently. Problem-based learning is one of the learning models associated with contextual learning. Learning is faced with a problem which then through the problem students learn more basic skills including communication skills. The problems discussed can be in the realistic context that students might face in the future. [6]

The main objective of this study was to develop a practical practicum guide using a microscope with a 
mentorship approach using a Problem Based Learning Model. The development of the guide is intended to follow the steps of the development method up to the guiding test, which is practicing. There are several students who are trained to become mentors. Through mentoring activities, reviews of the work results of study groups will be reviewed to be improved. Development of this learning is expected to be able to obtain a quality practicum guide that will facilitate practicum-based lectures. Mentorship is a relationship where people who are more experienced or more knowledgeable help / guide people who are less experienced or less knowledgeable. The mentor may be older or younger than the person being guided, but he must have certain areas of expertise [7]. Mentorship and relationship structure influence "the amount of psychosocial support [8], career guidance, role modeling, and communication that occur in a mentoring relationship where protégés and mentors are involved. Mentors can act as parents [9].

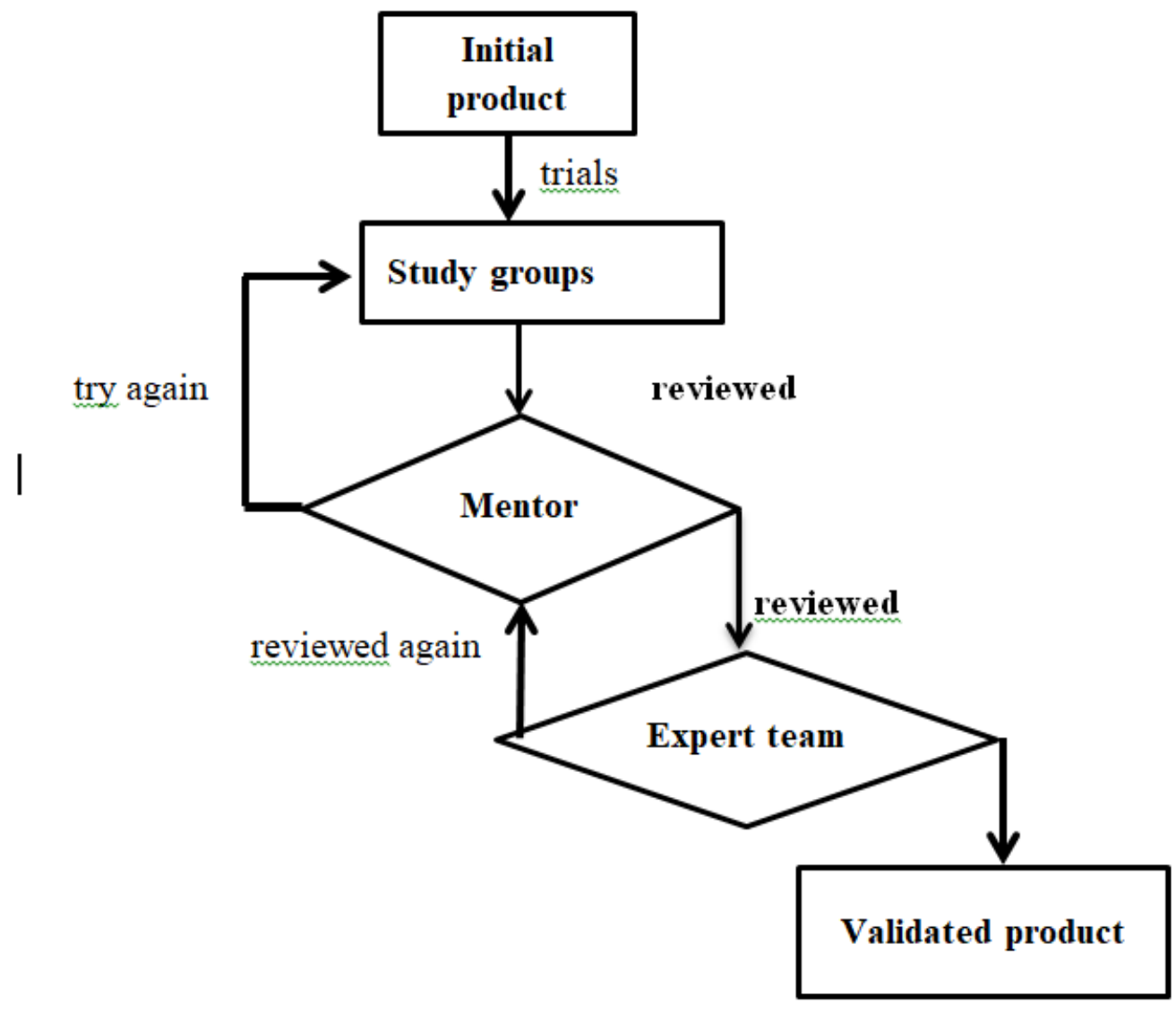

Figure 1. Stages of guide validation

Mentoring is a process for informal transmission knowledge, social capital, and psychosocial support felt by recipients as relevant for work, career, or professional development Mentoring requires informal communication, usually face-to-face and over a period of time, between someone who is considered to have knowledge, wisdom, or more relevant experience (mentor) and someone who is considered to have less than the one being guided. [10] Based on the results of the study, the American Institute of Physics also shows that collaborative small groups are the most convincing activity for the learning environment [6]. instruction from learning interactions in groups ok small is very important in developing student activity-based learning.

\section{Research Method}

This research was conducted in the even semester of the 2018/2019 academic year from April to May in the Laboratory of the Department of Physics, FMIPA, Manado State University with the main activity of developing a practicum guide using a Microscope. This study uses a development research method consisting of four stages, namely define, design, develop, and disseminate. Thus written by Thiagarajan, 1974 [11]. The Define Phase sets and defines the learning conditions beginning with an analysis of the practicum objectives to be developed. This stage includes 5 main steps, namely analysis of the front end, student analysis, task analysis, analysis of concepts, formulation of the objectives of developing a practicum guide.

Design Phase, designing guidelines using a problem-based learning model. The Develop Phase includes making the initial product that will be tested for validity. The process of validation and revision is done through mentoring and carried out in stages. The initial product was piloted to study groups then the group work results 
were reviewed by the mentor and the results of the review of the mentor were submitted to the expert team for review. The results of the expert examination are submitted back to the mentor to look at which things need to be corrected and then submitted to the study groups. These learning groups answer back the tasks given then the results of the work to the study group are submitted to the mentor to be examined and so on so that satisfying results are obtained. The chart can be shown as follows: Implementation of practicum guidelines using a problembased learning model carried out by 3 study groups each consisting of 5 students.

The initial product trial follows figure 1 above where there is a mentor evaluation and expert team evaluation. Evaluations and trials will continue to be carried out until the results of the validation are good, namely until all stages of the experiment with the problem-based learning model are carried out correctly and the work results of the lab work have answered the practicum objectives.

Disseminate Stage (Spread)

The dissemination process is a final stage of development. Dissemination in development research is only done in a limited way, namely by conducting trials in groups of students in other classes with the aim of knowing the effectiveness of using the Microscope practicum guide

\section{Result and discussion}

In the design section the completeness of the practicum guide aspects observed include the formulation of practicum objectives, theoretical background, tools and materials, practical work procedures, effectiveness of use, efficiency of use. Implementation of stages / work practicum activities observed are formulating problems, formulating hypotheses, arranging experiments, collecting data, testing hypotheses, and formulating conclusions. The results of the study relate to the assessment of the practical guideline design based on the completeness of the elements in the practicum guide showing that the percentage of completeness guidelines after revision 1 was $37.5 \%$, after review- 2 was $70.83 \%$ and in review 3 it was $95.83 \%$. Recommendation review 1 asks each group to complete the theory of using a microscope, labeling the images of microscope parts and completing the work procedures for practicing the lab. Recommendations after reviewing the two study groups were asked to perfect the names of each part of the microscope tool, edit the sentence in the lab work procedure which was not yet appropriate. After review-3, the elements in the guide increasingly meet standards including elements of efficiency and effectiveness in the use of practicum guidelines. Furthermore, in the small group trials for the impelmentation of the problembased learning model, the results of the study showed a pattern of changes in the ability of the learning group to experience positive developments as shown in the following figure:

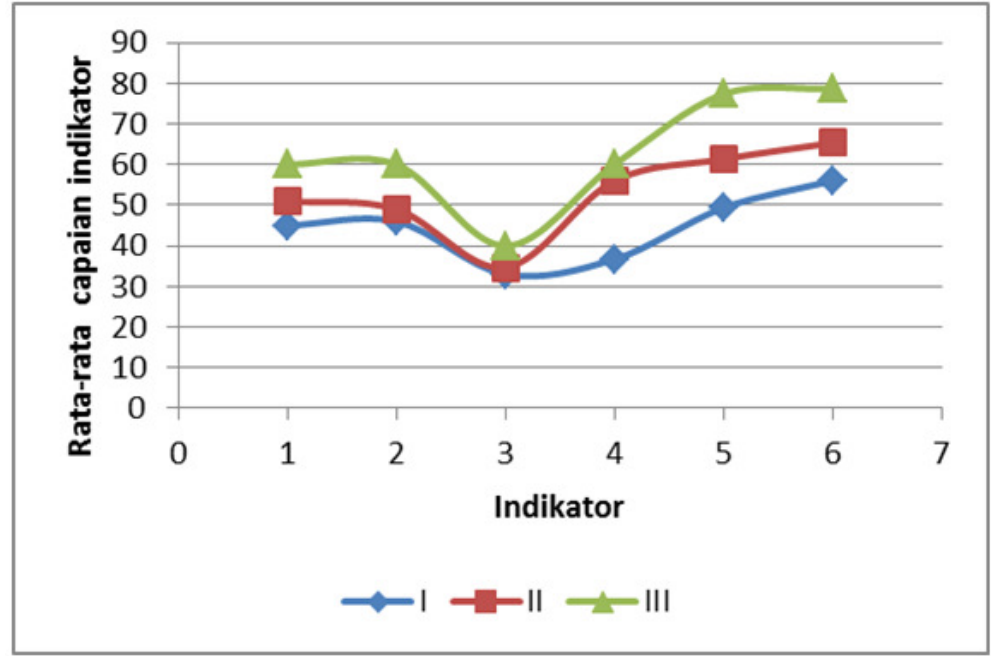

Figure 2. Graph of group work achievement for each indicator stage of practicum After review 1,2 and 3

The results of repeated examinations of the completeness of the practicum guide show students increasingly understand the elements needed in a practical guide and other things that can be seen also that students are able to discuss among group members, between different groups and sharing with lecturers so as to minimize differences in socio-economic status and the level of intelligence and work the team can build. [12]

Figure 2 above provides information that the review carried out with a tiered and repetitive mentoring approach greatly helps improve individual and group learning performance. Through the first and second experience, so that after the 3-level review all groups scored close to the perfect score for each indicator.

The results of field tests for students taking basic physics 2 as many as 20 people who were asked for opinions on the use of guidelines and practicum implementation showed that $62.5 \%$ of students gave a choice of the category "Strongly Agree", $36.25 \%$ of students gave the choice of "Agree" there is $1.25 \%$ for the choice of "Disagree" category and no student gives a choice of "Disagree" category. Based on this data shows that there are $98.75 \%$ of 
the number of students who respond positively to the use of practicum guides.

After being analyzed on aspects of performance, cognitive aspects, and psychomotor aspects each student gets a score in the range of 70-90 with achievement above $70 \%$. The results of the responses of small groups of students, large groups and dissemination stages where more than $90 \%$ gave positive responses and this shows that practicum guides made in simple language with clear worksheets make students happy and interested in practicing using a microscope. Through mentoring activities for small groups of students, it can be directed and guided how to compile a standard practicum guide, carry out practical activities and analyze practical results. The experience of prospective teacher students in compiling guidelines and practicum can improve their competence as prospective professional teachers, because learning physics cannot be separated from the science process. Through practicum activities while solving problems, students also act like scientists in conducting laboratory activities, this is also conveyed in Sotiriou, S [13]. Students as prospective teachers get a wealth of experience and teaching skills such as interaction and communication as well as classroom management. This is also in line with the results of research conducted by Diala Hamaidi, et al. [14]

\section{Conclusion}

Based on the description and explanation above, the research conclusions can be stated as follows: Practical guide using microscope equipment arranged according to the stages of development research includes the results of assessment of reviewers / expert teams, guiding trials to small groups and large groups up to the results of the analysis indicating that this practicum guide is said to be valid or feasible to be used in basic physics practicum activities especially in the practice of optical instruments using a microscope with a problem-based learning model with a mentoring approach.

\section{References}

[1]. Fekede Tuli And Gemechis File.2009. Practicum experience in teacher education Ethiop. J. Educ. \& Sc. Vol. 5 No 1 September 2009

[2] Kurbanoglu, N. I., \&Akim, A. (2010).The relationships between university students' chemistry laboratory anxiety, attitudes, and self-Efficacy beliefs.Australian Journal of Teacher Education, 35(8), 48-59

[3].Evrim, U. 2019. The Effect of Guided-Inquiry Laboratory Experiments on Science Education Students' Chemistry Laboratory Attitudes, Anxiety and Achievement.Correspondence:Evrim Ural, Faculty of Education; Primary School Teaching Department, KahramanmaraşSütçü İmam University, Turkey

[4] Vida V.M. 2018. Science Laboratory Interest and Preferences of Teacher Education Students: Implications to Science Teaching. Laoag City, Philippines. Asia Pacific Journal of Multidisciplinary Research, Vol. 6, No. 3, August 2018

[5]. Jacobsen, D. A., Eggen, Paul, \& Kauchak, Donald. (2009). Methods for teaching

[6] Oon-Seng Tan (2009). Problem-based learning and creativity. Singapore: Cengage Learning.

[7]. Caela, F.2006. ight Types of Mentors: Which Ones Do Your Need? MasteryWorks, Inc. Reprints available by contacting MasteryWorks, Inc. 1-800-229-5712

[8]. Fagenson-Eland, Ellen A.; Marks, Michelle A.; Amendola, Karen L. (1997). "Perceptions of mentoring relationships". Journal of Vocational Behavior. 51 (1): 29-42. doi:10.1006/jvbe.1997.1592

[9]. Lindy Nahmad-Williams,2019. Experimenting with dialogic mentoring: a new model Copyright 2019 Emerald Publishing Limited

[10].Bozeman, B.; Feeney, M. K. (October 2007). "Toward a useful theory of mentoring: A conceptual analysis and critique". Administration \& Society. 39 (6): 719-739. doi:10.1177/0095399707304119. Archived from the original on 2013-01-05.

[11]. Mawardi,2016.The Development of Guided Inquiry-based Worksheet on Colligative Properties of Solution for Chemistry Learning. $1^{\text {st }}$ International Conference of Mathematics and science education (ICMSEd 2016)

12]. Alison B. 2011. Group Work: How to Use Groups Effectively Southern Oregon University, Ashland, OR 97520.The Journal of Effective Teaching, Vol. 11, No. 2, 2011, 87-95 C2011

[13]. Sotiriou, S., \& Bogner, F. X. (2015).A 2200-Year Old Inquiry-Based, Hands-On Experiment in Today's Science Classrooms. World Journal of Education, 5(2), 52-62. http://dx.doi.org/10.5430/wje.v5n2p52

[14] Diala H, Ibrahim A, Yousef Arouri.,Ferial A.2014. Student-teachers's perspectives of. Practicum practices and challenges. European Scientific Journal May 2014 edition vol.10, No.13 ISSN: 1857 - 7881 (Print) e ISSN 1857- 7431 